\title{
AIR FLOW INFLUENCE AT LOW HUMIDITY LAYER FORAGE IN CONSERVATION TECHNOLOGY
}

\author{
Ana Zaica ${ }^{1}$, Radu Ciuperca ${ }^{1}$, Alexandru Zaica ${ }^{1}$, Diana Popa ${ }^{2}$
}

${ }^{1}$ National Institute of Research-Development for Machines and Installations Designed to Agriculture and Food Industry, Romania; ${ }^{2}$ Agricultural Research and Development Station Secuieni, Romania zaica_ana@yahoo.com, ciupercaradu@yahoo.com, zaica_alexandru@yahoo.com, dy.hemp420@gmail.com

\begin{abstract}
The fodder plants necessary in the field of animal husbandry have an essential characteristic, namely, the full use of plant mass, thus, imprinting their more efficient use in environmental conditions, it is among the intensive crops. The technology of conservation of fodder plants is useful for the capitalization of fodder from meadows and fodder crops, especially from the surfaces in the hilly and mountainous areas. The areas of the exploited meadows must ensure the necessary animal feed throughout the year. The article addresses certain experimental aspects of how it influences the environment of the aeration process in order to dry the fodder plants, a technology based on conservation, storage and maintenance of the nutritional qualities of the fodder. In the technology of drying fodder with heated air, it is necessary to continuously control the temperature in the fodder mass during the aeration process. The results of the experimental research were carried out in a technology to reduce the drying time from harvesting the fodder plants to obtaining hay at the storage humidity. A special aeration installation with a monitoring and control system of work processes was used to carry out the research. During the research the environmental parameters were analysed, the flow and the parameters of the aerating agent (temperature and humidity), as well as the characteristics of the feed mass structure: humidity, temperature, drying uniformity, obtaining information on their influence on reducing the drying time. In the controlled process of feeding aeration, conducted in climatic conditions, there is additionally an influence of the linear speed of the aerating agent on the duration of the process, the degree of humidity of the feed, at approx. $18 \%$, recommended for preservation.
\end{abstract}

Keywords: drying technology, animals, hay, and loss humidity.

\section{Introduction}

Agriculture is the most important constituent of the human environment, the need to adopt and expand good agricultural practices, as well as finding ways and technologies of plant cultivation, which harmonize with the specific requirements of organic farming, in order to preserve a natural landscape and an environment in which soil, water, wild plants and animals, crops and domestic animals, including humans, live in harmony [1].

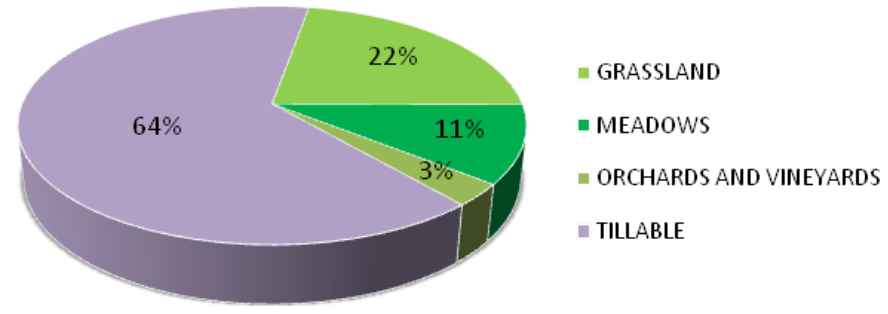

Fig. 1. Agricultural area according to the mode of use

The multifunctionality of the meadows, Fig.1, is offered by the main functions performed by them:

- provide the necessary feed for at least $60 \%$ of the cattle herd and $80 \%$ of the sheep herd;

- the economic function refers to all related activities resulting from the use and capitalization of meadows, such as processing of animal products, collecting medicinal flora, beekeeping, etc.;

- habitat function for wildlife and biodiversity conservation of plant and animal species;

- ecological function, protection of the soil against the phenomenon of erosion and conservation of the natural space.

The contribution of meadows at the production of fodder useful for the development of animal husbandry is of notable importance, because fodder with a good floristic composition, with a complete nutritional value, having a balanced composition in protein, vitamins, salts and other substances is the staple food of ruminants [2]. 
Harvesting and preparation technologies are chosen according to the species of fodder being harvested, the soil and climatic conditions and the calendar period in which the harvesting is carried out. For the choice of harvesting and preparation technology, it is taken into account that the quantitative and qualitative losses are minimal, by making maximum use of the biochemical properties of selfpreservation of feed.

An essential factor, which directly influences the choice of the harvesting technology, is the degree of endowment with mechanical means and labour required. The execution of the predominantly mechanized technology, with high yield, of the harvesting and preparation of fodder, allows both obtaining of high-quality fodder and creation of the possibilities to obtain several harvests per year $[2 ; 4]$. Internationally, the method of preparing vitamin hay has been extended by minimizing the quality losses of fodder after harvest, losses due, first of all, to long exposure to climatic factors after mowing, and, on the other hand, to leaf losses by shaking [3].Mowed fodder is dried on stubble by intensive preparation (by crushing, breaking or defibrating with mowing, by twisting and turning) to a humidity of $30 \ldots 45 \%$, after which it is collected, transported, then stored on dryers or special covered hayfields, where drying of the fodder is completed until the storage humidity of less than $17 \%$ by air ventilation (cold or hot). A remarkable topical development is the installations with solar collectors that allow preheating and monitoring of the air necessary for ventilation, which leads to a substantial reduction of the necessary period until the hay storage humidity is reached [4].

\section{Materials and methods}

Preparation and preservation of feed with the help of air currents - is the best method and consists in the forced drying of plants using ventilation with cold or hot air. This method eliminates water in a very short time and the loss of nutrients is reduced [5]. Although the installations are not very expensive, they are amortized by avoiding quantitative and qualitative losses very quickly, however, due to the high consumption of conventional energy or fossil fuels, the method has a limited applicability. It is recommended to prepare hay using these methods, consisting of a mixture of fodder plants and cultivated legumes. The feed thus prepared has approx. 63\% more protein, with approx. $13 \%$ more fat and approx. 10 times more carotene than dry hay through the furrow $[5 ; 6]$.

Due to the need to reduce conventional energy consumption, specialists have sought solutions for construction of fodder drying facilities with hot air produced in solar, geothermal or biogas plants, especially in the case of livestock farms that have facilities for its production. These technologies can achieve significant savings in fuel and electricity.
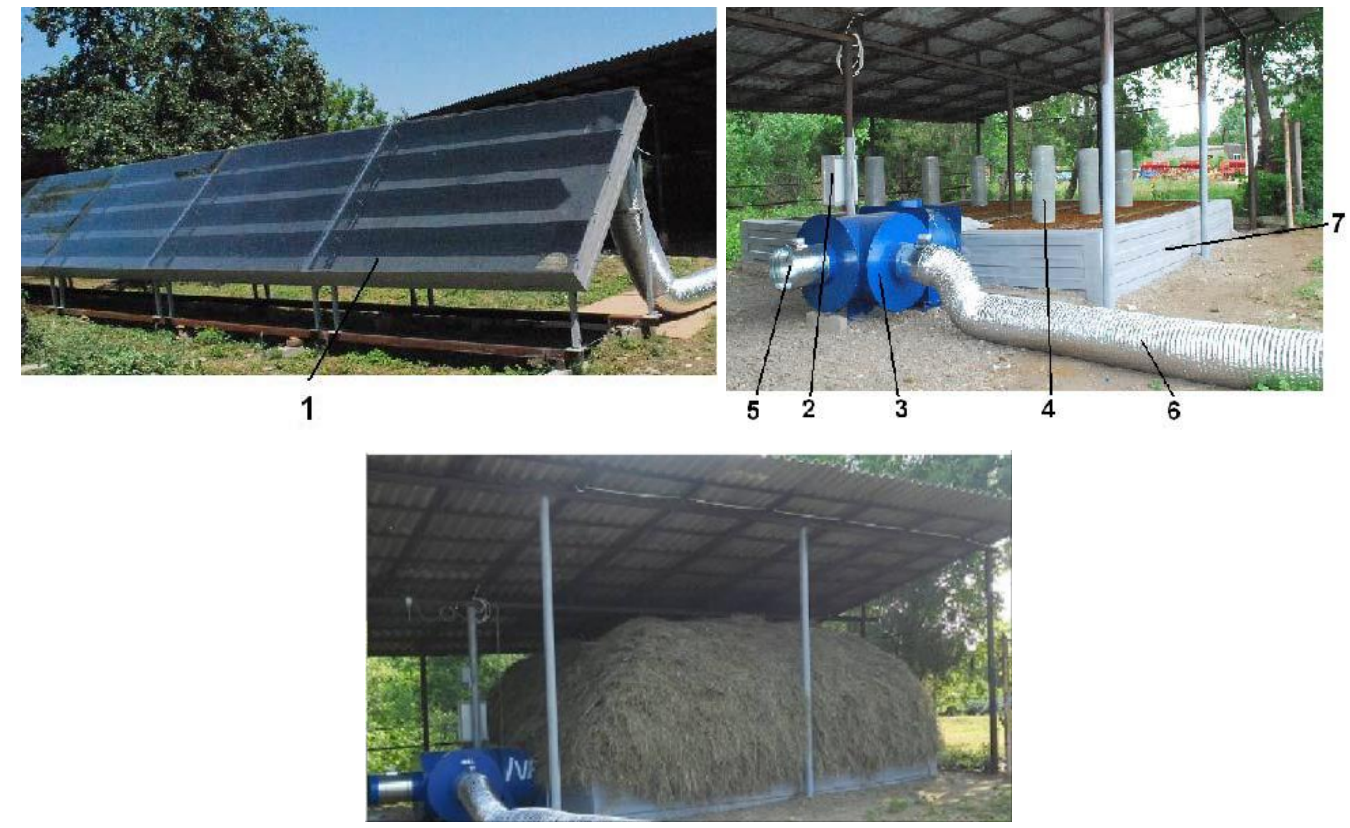

Fig. 2. Experimental model of the installation for fodder ventilation, IVF: 1 - assembled solar panel; 2 - electrical installation; 3 - ventilation equipment; 4 - ventilation tubes; 5 -intake flanges with electric motor; 6 - piping for hot air circuit; 7 - drying/storage platform 
The hay drying plant by cold or hot air ventilation, symbolized IVF, (Fig. 2) used for experiments, is built of assemblies developed in a modular structure (e.g., solar panel, storage platform) for users and configure the drying plant according to the needs of the farm [5; 7].

The drying system (Fig. 3) also includes an electrical installation that ensures the operation of the fan, the command and control of the ventilation process.
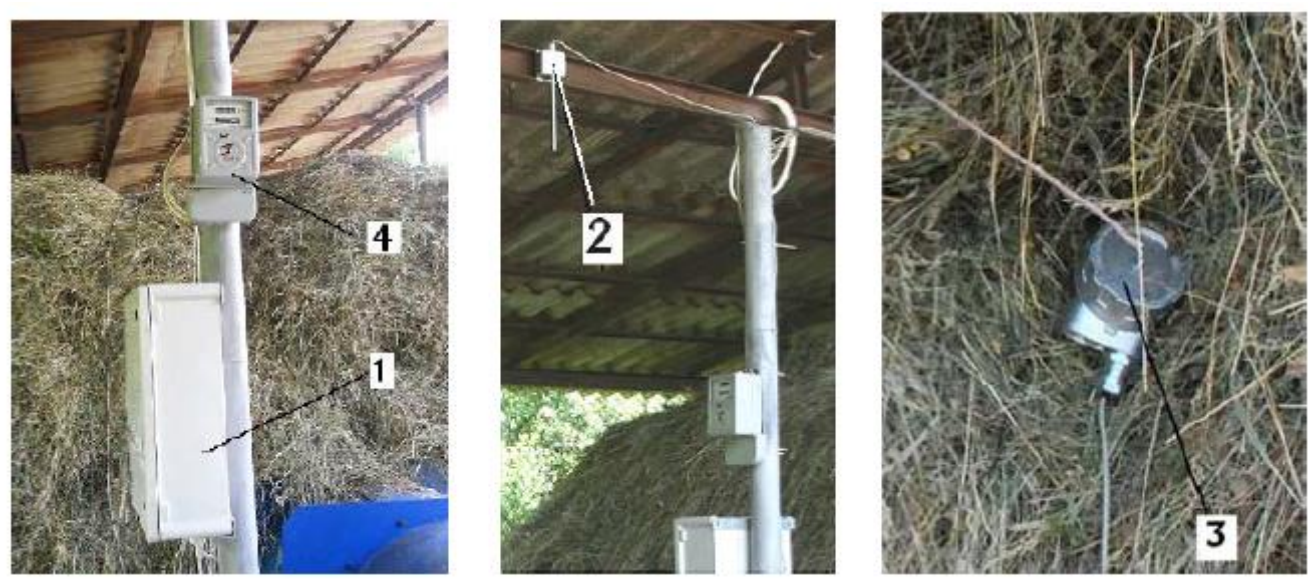

Fig. 3. Electrical command and control system: 1 - control panel; 2 - sensor for measuring atmospheric air temperature and humidity; 3 - sensor for measuring the temperature in the feed layer; 4 - electric meter

The control panel of the installation (Fig. 2, Pos.1) is equipped with Micro PLC, which receives information from the temperature and humidity sensors, allows adjustment of the input parameters, as well as the control, respectively, monitoring of the installation.

The phases of the technology of drying fodder by air ventilation are:

1. harvesting the furrows of the plants, at a humidity of $80 \ldots 85 \%$;

2. drying in furrows until it reaches a humidity of $35 \ldots 40 \%$;

3. assembly and immediate transport of feed for storage on the drying platform;

4. finalizing the drying by ventilation with cold air or hot air, until a humidity of about $17 \%$ is reached [6].

Stages of air ventilation drying $[7 ; 8]$.

- When the mowed fodder has a humidity of $35 . . .40 \%$, it is collected from the pasture and transported to the drying plant.

- The feed is placed on the drying platform, if possible, on the length of $8 \ldots 10 \mathrm{~m}$, up to a height of $3.5 \ldots 4 \mathrm{~m}$; the work is recommended to be done in a day, after which the fan is put into operation. Or if the drying is done in several stages, when the first feed layer has reached a height of $1 \ldots 1.5 \mathrm{~m}$, the fan is put into operation, the feed layer is completed up to a height of $3.5 \ldots 4 \mathrm{~m}$.

- The vent rises/extends to the maximum height, so that it is at the same level.

- The drying time of a layer of hay depends on the size of the layer and the atmospheric conditions.

- The drying of the feed is considered completed, when the humidity of the last layer has dropped below $20 \%$, or when the internal temperature stabilizes at $20{ }^{\circ} \mathrm{C}$ and after an interruption of 12 nu 24 hours there is no heating of the feed.

- Control: after a break of $12 \ldots 14$ hours the fan is switched on and if the air coming out of the feed is cold, it means that the drying is finished, and the feed will be kept without losses. If the air coming out of the feed is warm, ventilate until it is completely dry.

Operation of the drying system by ventilation with falling air or cold air.

1. Load the feed on the platform.

2. The installation is connected to the electricity source. 
3. The PT 100 thermoreceptor and the humidity sensor are inserted in the fan and connected to the electrical installation.

4. Adjust the converter according to the air flow required for ventilation.

5. Turn on the fan and ventilate the hay according to the ventilation program.

6. The hay drying process is monitored:

- the weather parameters are measured - temperature, humidity, pressure, wind speed, etc.;

- the temperature in the hay is measured with a sensor located in the hay;

- the temperature in the feed mass is monitored: in the pause between two vents, if the temperature in the feed mass increases to a value above $30^{\circ} \mathrm{C}$, the electrical and control installation, through the safety program set in Micro PLS, controls the fan start, eliminating that there is a danger of heating the feed;

- samples are sampled daily to determine the humidity of the hay.

7. The drying is considered complete when the internal temperature stabilizes at $20{ }^{\circ} \mathrm{C}$ and after an interruption of $12 \ldots 24$ hours the feed does not heat up.

Daily monitoring of weather parameters until the completion of feed drying (temperature, humidity, pressure, etc.), as well as determining the input and output parameters in the drying process, namely: ventilation duration; fan air flow; linear velocity of air flow in the feed layer (in various areas of the platform); feed moisture; electricity consumption; temperature in the solar panel/tubing and the temperature in the feed mass, become the important parameters of the optimization of the drying process $[8 ; 9]$.

Because it is found that there are a number of parameters that may have an influence on the aeration process, but not all have the same influence, determinations were made only for some of them during the experiments.

The identification of the decisive factors that become the parameters of the drying process is a particularly important activity given that the materials subjected to the drying process are thermolabile products with a certain degree of humidity, on which both the temperature level and the degree of humidity of the drying agent is of particular importance. Factors that directly influence the drying process are mainly the temperature and humidity of the drying material, the drying agent and the dry material.

In order to optimize the drying process that takes place in feed aeration installations, it is necessary to approach more deeply the study of air circulation in the stored layer. The study can be performed using the similarity with the theories underlying the process of fluidization through porous layers, the feed having the characteristics of a porous material both in the structure and in the layer state.

The strength of the feed layer encountered by the fan air flow depends on the thickness of the layer and the type of feed. The feed layer made of a structure of grass and legume mixtures has a higher resistance to air flow being considered a porous medium by its shape, and also by the structure of the component plants. When air currents are sent into the feed mass, the air pressure decreases depending on the air speed and the distance between the individual feed particles and the so-called pressure drop occurs [10-13].

\section{Results and discussion}

Ventilation installation of bulk feed by ventilation with cold or hot air, IVF symbol, was used in operating conditions in the feed warehouse arranged at INMA Bucharest, according to the methodology of tests developed. The hay needed for the samples was harvested from an experimental lot, with the grasses growing spontaneously. The equipment, instruments and auxiliary materials used were those from the endowment of the INMA and ICDP Braşov Laboratories.

The air temperature and humidity, as well as the temperature in the hay were measured with the temperature sensors placed in the hay and in the warehouse, and the values were read on the Micro PLS display from the command-and-control panel of the installation, Fig. 3.

In order to measure the humidity of the feed during the aeration process, samples were collected from four different areas of the platform, in order to check if the hay dries evenly.

The drying uniformity of the feed on the ventilation platform was determined using relation $1,[1]$ : 


$$
U_{u}=\left(1-\frac{\sqrt{\frac{\sum_{1}^{n}\left(u_{i}-u_{m}\right)^{2}}{n-1}}}{u_{m}}\right) \cdot 100,
$$

where $U_{u}-$ drying uniformity of the feed on the drying platform, \%;

$u_{i}-$ feed moisture at the sampling point $i$, \%;

$n$ - number of moisture samples taken from the feed mass subjected to drying;

$u_{m}$ - average moisture content of the feed, \%, determined by the relation 2, [1]:

$$
u_{m}=\frac{\sum_{1}^{n} u_{i}}{n},
$$

The time schedule of the process of drying by ventilating the feed from the moment of placing it on the platform of the installation and until obtaining the storage humidity is presented in Table 1.

Table 1

\begin{tabular}{|c|c|c|c|c|c|c|c|c|c|c|}
\hline \multirow[t]{2}{*}{ Day } & \multirow{2}{*}{$\begin{array}{c}\text { Duration and } \\
\text { type of } \\
\text { ventilation, } \\
\text { in hours }\end{array}$} & \multirow{2}{*}{\begin{tabular}{|} 
Linear \\
speed of air \\
in the feed \\
mass, $\mathbf{m} \cdot \mathrm{s}^{-1}$
\end{tabular}} & \multicolumn{4}{|c|}{$\begin{array}{c}\text { Mass feed } \\
\text { temperature, } \\
{ }^{\circ} \mathrm{C}\end{array}$} & \multicolumn{2}{|c|}{$\begin{array}{c}\text { Moisture of } \\
\text { samples, } \\
\%\end{array}$} & \multirow{2}{*}{$\begin{array}{c}\text { Linear } \\
\text { speed in the } \\
\text { uniforming } \\
\text { chamber, } \\
\mathrm{m} \cdot \mathrm{s}^{-1}\end{array}$} & \multirow{2}{*}{$\begin{array}{c}\text { Electricity } \\
\text { consumption, } \\
\text { kWh }\end{array}$} \\
\hline & & & I & II & III & IV & $\begin{array}{c}\text { Ora } \\
8\end{array}$ & $\begin{array}{c}\text { Ora } \\
14\end{array}$ & & \\
\hline 1 & $8 \mathrm{~h}$ cold air & $0.1 \ldots 0.3$ & 25 & 26 & 26 & 27 & 35.15 & 34.15 & $1 \ldots 2$ & 32 \\
\hline 2 & $\begin{array}{l}5 \mathrm{~h}: 4 \mathrm{~h} \text { cold air } \\
\text { and } 1 \mathrm{~h} \text { hot air }\end{array}$ & $0.1 \ldots 0.2$ & 26 & 26 & 26 & 27 & 32.10 & 27 & $1 \ldots 2$ & 20 \\
\hline 3 & $\begin{array}{l}5 \mathrm{~h}: 4 \mathrm{~h} \text { cold air } \\
\text { and } 1 \mathrm{~h} \text { hot air }\end{array}$ & $0.1 \ldots 0.2$ & 25 & 26 & 26 & 26 & 26.63 & 23.44 & $1 \ldots 2$ & 20 \\
\hline 4 & No ventilation & - & 24 & 24 & 25 & 24 & - & - & - & - \\
\hline 5 & $1 \mathrm{~h}$ cold air & $0.1 \ldots 0.2$ & 23 & 24 & 24 & 24 & 19.62 & 18.56 & $1 \ldots 2$ & 4 \\
\hline 6 & $1 \mathrm{~h}$ cold air & $0.1 \ldots 0.3$ & 22 & 23 & 20 & 20 & 17.64 & 17.48 & $1 \ldots 2$ & 4 \\
\hline 7 & $1 \mathrm{~h}$ cold air & $0.1 \ldots 0.2$ & 20 & 21 & 20 & 20 & 17.3 & 15.66 & $1 \ldots 2$ & 4 \\
\hline 8 & No ventilation & - & 20 & 20 & 21 & 20 & 15.92 & 15.03 & - & - \\
\hline & 84 \\
\hline
\end{tabular}

Time calendar of the drying process by feed ventilation

Table 1 presents a series of results obtained as a result of testing the experimental model, such as: the ventilation period determined by the correlation of the linear velocity of the air in the feed mass and the linear velocity in the uniformization chamber (Fig.1, Pos.7), results in temperature and humidity in the feed mass.

Following the experiments, it was proved that the researched solar panel provides the warm air necessary to complete the drying of the hay by ventilation, when it is necessary to use it according to the established methodology. It was confirmed that the temperature in the solar panel is influenced by solar radiation and atmospheric air temperature causing the variation of the temperature of the aerating agent in the uniformization chamber at different intervals during the days, Fig. 4.

Comparing the variation of the two parameters, Table 1, humidity and temperature, it is found that their development is inversely proportional, so the humidity decreases when the temperature rises, and has been fluctuating from day to day. In these circumstances, according to the methodology it was ventilated between the hours 8 ...14.

The aeration of the feeds performed in the climatic conditions registered in the studied period supplemented by the linear speed of the aeration agent within the technology influenced the duration of the aeration process, the degree of humidity of the feeds, at approx. $18 \%$, recommended for preservation, process performed in 21 hours of ventilation, respectively 7 days (Fig.4 and Fig.5). 


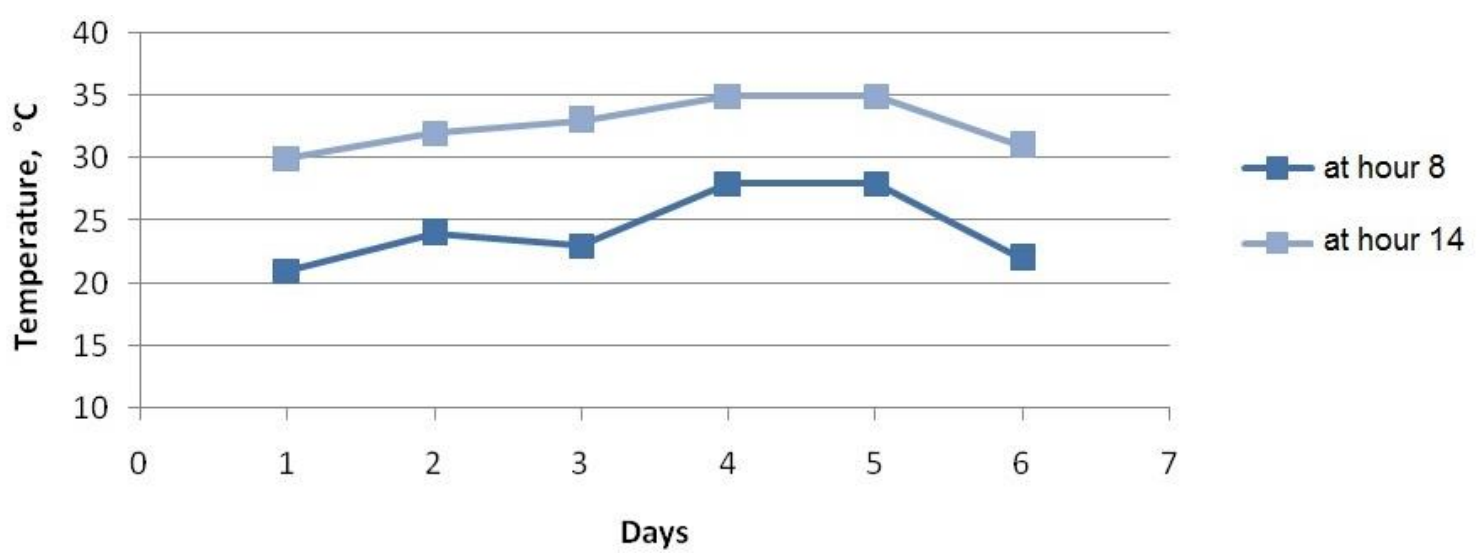

Fig. 4. Variation of the temperature of the aerating agent in the uniforming chamber at different intervals of the day

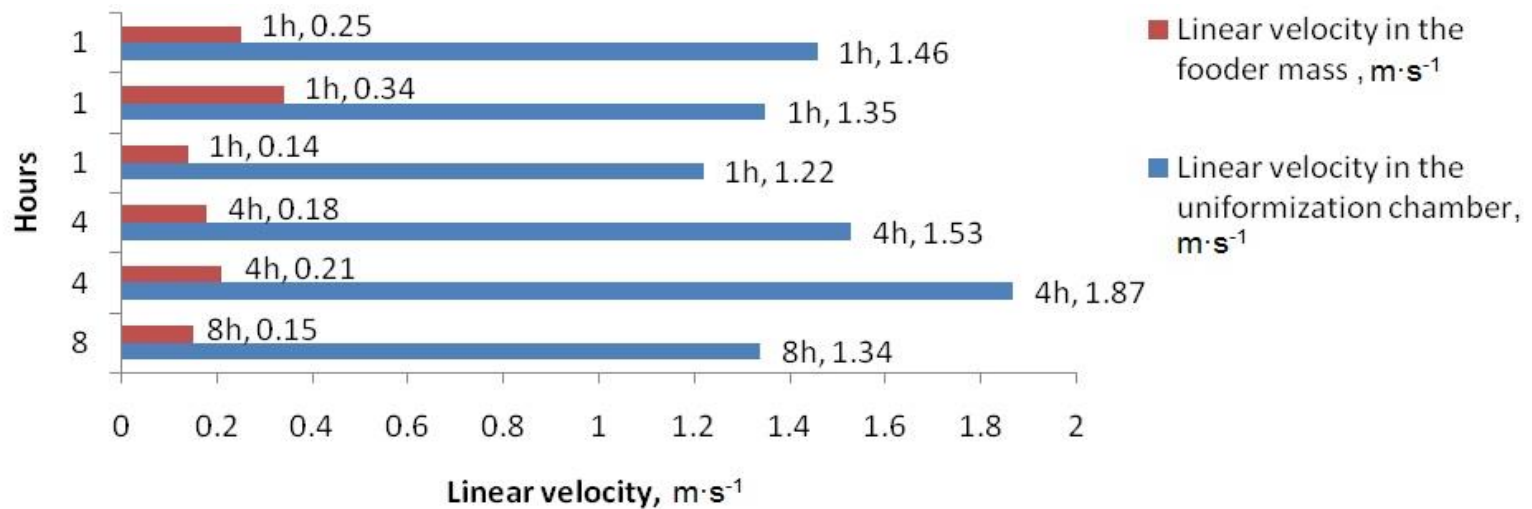

Fig. 5. Variation of the linear speed of the aerating agent in the uniformization chamber, as well as in the feed mass, during the ventilation process

The results of the experiments under operating conditions are presented in Table 2.

Table 2

Results in experimental conditions

\begin{tabular}{|l|c|c|}
\hline \multicolumn{1}{|c|}{ Specification } & UM & Obtained value \\
\hline Straw drying time of feed & $\mathrm{h}$ & 32 \\
\hline $\begin{array}{l}\text { Amount of water evaporated from the feed during the drying } \\
\text { phase on the stubble }\end{array}$ & $\mathrm{kg}$ & 7020 \\
\hline $\begin{array}{l}\text { Total duration of final drying of hay by ventilation, } \\
\text { of which: - with cold air } \\
\text { - with hot air }\end{array}$ & ore & 21 \\
\cline { 2 - 3 } & & 19 \\
\hline Average humidity of the feed at the end of the drying installation & $\%$ & 2 \\
\hline Amount of hay obtained at the end of drying & $\mathrm{kg}$ & 30.48 \\
\hline $\begin{array}{l}\text { Amount of water evaporated from the feed in the final phase of } \\
\text { drying by ventilation }\end{array}$ & $\mathrm{kg}$ & 816 \\
\hline Uniformity of drying the feed on the ventilation platform & $\%$ & 97.5 \\
\hline Specific drying capacity of the installation & $\mathrm{kg} \cdot \mathrm{m}^{-2}$ & 84.55 \\
\hline Electricity consumption & $\mathrm{kWh}^{-1}$ & 84 \\
\hline Specific electricity consumption per kg of dry fodder & $\mathrm{kWh} \cdot \mathrm{kg}^{-1} \mathrm{hay}$ & 0.0276 \\
\hline $\begin{array}{l}\text { Specific consumption of electricity per kg of water removed from } \\
\text { feed by ventilation }\end{array}$ & $\begin{array}{c}\mathrm{kWh} \cdot \mathrm{kg}^{-1} \\
\mathrm{evacuate} \text { water }\end{array}$ & 0.13 \\
\hline
\end{tabular}

In order to determine the drying uniformity of the feed on the drying platform, Table 2, 6 moisture samples were taken from the following points: middle left; left back corner; left outer corner; middle right side; right back corner; right outer corner. The following humidity values resulted: $15.96 \%$; 
$16.56 \% ; 17.3 \% ; 15.66 \% ; 16.28 \%$ and $17.1 \%$, which were the data bases for calculating the drying uniformity.

Table 3

Working index values measured for ventilation with cold air and heated air

\begin{tabular}{|l|c|c|c|c|}
\hline \multicolumn{1}{|c|}{ Parameters } & \multicolumn{4}{c|}{ Day 1, hour } \\
\cline { 2 - 5 } & $\mathbf{8}$ & $\mathbf{1 0}$ & $\mathbf{1 2}$ & $\mathbf{1 4}$ \\
\hline Atmospheric air speed, $\mathrm{m} \cdot \mathrm{s}^{-1}$ & 1.61 & 1.71 & 1.84 & 1.84 \\
\hline Air speed at the entrance to the panel, $\mathrm{m} \cdot \mathrm{s}^{-1}$ & 2.4 & 2.5 & 2.4 & 2.4 \\
\hline Air velocity at the exit of the panel, $\mathrm{m} \cdot \mathrm{s}^{-1}$ & 2.5 & 2.5 & 2.4 & 2.5 \\
\hline $\begin{array}{l}\text { Air velocity at the entrance to the uniforming chamber, } \\
\mathrm{m} \cdot \mathrm{s}^{-1}\end{array}$ & 23 & 24 & 23 & 23 \\
\hline Air speed in the uniforming chamber, $\mathrm{m} \cdot \mathrm{s}^{-1}$ & $1 \ldots .2$ & $1 \ldots 2$ & $1 \ldots .2$ & $1 \ldots .2$ \\
\hline Atmospheric air temperature, ${ }^{\circ} \mathrm{C}$ & 23.5 & 25.5 & 27.5 & 28.5 \\
\hline $\begin{array}{l}\text { Temperature in the panel at the beginning of ventilation, } \\
{ }^{\circ} \mathrm{C}\end{array}$ & 25.4 & 55.2 & 60.3 & 63 \\
\hline Panel temperature after $15 \mathrm{minutes}$ of ventilation, ${ }^{\circ} \mathrm{C}$ & 23 & 30 & 35 & 37 \\
\hline Platform temperature during hot air ventilation, ${ }^{\circ} \mathrm{C}$ & 24 & 30 & 32 & 33 \\
\hline Average temperature in the hay, ${ }^{\circ} \mathrm{C}$ & 25 & 26 & 26 & 27 \\
\hline
\end{tabular}

During hot air ventilation the temperature in the platform uniformization chamber (Fig.1, Pos. 7) increases at the beginning, compared to the atmospheric air temperature, because the hot air ventilation is followed by the cold air ventilation, the room temperature becomes uniform in approx. $5 \mathrm{~min}$, so that a difference of max. $8{ }^{\circ} \mathrm{C}$ compared to the atmospheric air temperature is gradually decreasing towards the outside air temperature.

In the same way, Fig. 5, as the pressure drop of the fluid varies with the speed of circulation, the porosity of the layer also varies. At low speeds, the pressure force is not sufficient to produce a variation in the structure of the layer, nor in its porosity, but at higher speeds, the layer expands, increasing the volume of the void.

During the experimentation period some particularities were observed, such as: high atmospheric temperatures $\left(\mathrm{T},{ }^{\circ} \mathrm{C}\right.$, atm. air) and low air humidity (U, \%, atm. air). The material subjected to the aeration process is composed of a mixture of fodder plants harvested from the grassland. The experimental research for the analysed period had been carried out for 7 days, during 21 effective hours of the aeration drying process of the material deposited on the installation platform, interpreted in graphic form below showing the influence of the linear velocity variation of the air used as the drying agent, Fig. 6.

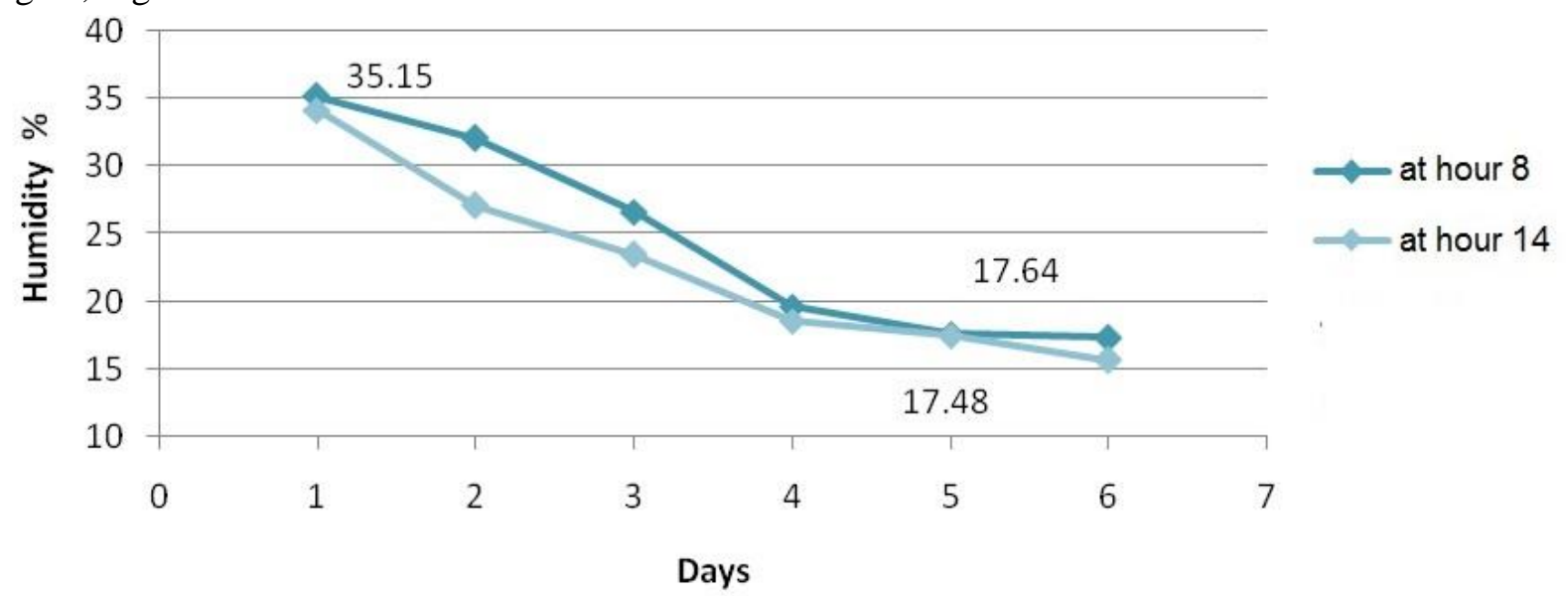

Fig. 6. Variation of moisture loss in the feed mass at different intervals of the day during the ventilation process 
From the graph it can be seen that from the 5th day of the ventilation process the optimum moisture for preserving the fodder is reached.

Although the feed used to test the installation was of a moderate quality from a nutritional point of view, coming from a natural hayfield, at the end of the experiments the following were found:

- hay mown from plants specific to spontaneous flora has a normal appearance, in advanced drying, without rotten or moldy plants, predominant color - light green;

- pleasant, faded smell, characteristic of the hay from the spontaneous flora;

- dry stems break easily; dry leaves shake easily.

\section{Conclusions}

1. The preservation of fodder on meadows in the form of hay are the basic works for obtaining a final product with a nutritional value as close as possible to the initial one of green fodder. Compared with cold air drying, hot air drying has the following advantages: 1 - reduces dependence on atmospheric conditions during harvesting; 2 - reduces the drying time of feed; 3 - the initial humidity of the fodder subjected to drying can be $10 \ldots 15 \%$ higher, which leads to obtaining even better quality hay. By additional drying of the hay with mechanical ventilation systems, the loss of nutrients is reduced by up to $25 \ldots 30 \%$ or even $50 \ldots 70 \%$ in unfavourable weather conditions.

2. Comparing the influence of the parameters humidity and temperature, by their variation it is found that their development is inversely proportional, so that the humidity decreases when the temperature increases. Under these conditions, according to the methodology and the controlled aeration process, the linear speed of the aeration agent also appears to a real extent.

3. The experimental research has shown that in order to observe a complementary influence with the temperature and humidity of the aerating agent, and the concrete influence of its air flow, pressure and speed in the feed mass, an adequate program of organizing experiments is required in a separate experimental research focused on varying these parameters of the aeration process.

\section{Acknowledgement}

This work was supported by a project of the Ministry of Research, Innovation and Digitization, through Programme NUCLEU - Project: PN 19100105 - Integrated management of agricultural works, viticulture and fruit farms, contract No. 5N/07.02.2019.

\section{References}

[1] Maruşca T., Mocanu V., Cardaşol V., Hermenean I., Blaj V.A., Oprea G., Tod M.A., Guide to the ecological production of mountain meadow fodder, Transilvania University Publishing House, Braşov, 2010.

[2] Romanian Statistical Yearbook, tab. 14.1, tab. 14.10, 2013. [online] [21.03.2021] Available at: http://www.madr.ro/docs/agricultura/agricultura-romaniei-2014.pdf, source:

[3] Aboltins A., Palabinskis J., Rušķis G. The investigations of heating process in solar air heating collector, Agronomy Research. No.8 (Special 1): Proceedings of the International scientific conference "Biosystems Engineering 2010", 2010, pp. 5-11.

[4] Sărăţeanu V., Preservation of fodder, Culture of meadows and fodder plants, Fascicula no. 03, 2005.

[5] Nedelcu A., Popa L, Ciupercă R, Research carried out with the installation for drying hay by ventilation with cold or hot air-IVF, Bulletin AGIR no.3, 2014, pp. 57-62.

[6] Dmytro Milko, Oleksandr Sclyar, Radmila Sclyar, Ganna Pedchenко, Dmytro Zhuravel, Bratishko Viacheslav, Results of the nutritional preservation research of the alfalfa laying on storage with two-phase compaction, INMATEH AGRICULTURAL ENGINEERING, Vol 60, No. 1, 2020, pg. 269-274.

[7] Nedelcu A., Technological study on the efficient harvesting, transport and conservation of herbaceous fodder plants, Technological study I.N.M.A. Bucharest, Program Project ADER 2020/736, 2011.

[8] Zaica A., Căsăndroiu T., Nedelcu A., Ciupercă R., Pirnă I., Lazăr G., Ștefan V., Theoretical aspects regarding the process of drying the fodder plants", TE-RE-RD 2015, 4th International Conference on Thermal Equipment, Renewable Energy and Rural Development, Posada - Vidraru, 2015, pp. 411-416. 
[9] Hermenean I., Mocanu V., Technologies, machines and installations for harvesting and preservation as hay of the fodder on grasslands, Transilvania University Publishing House, Brasov, 2008.

[10] Cioabla A., Călin L, Irimescu A., Optimization of the drying process of cereals under the conditions of reducing fuel consumption, AGIR Bulletin no. 2-3/2010, April-September, 2010.

[11] Frederiksen H., Dănuţ D., Maşinistru M., Greculescu A., Fodder storage systems - Farm Standards, Manual, Modernization of the Information and Knowledge System in Agriculture Project MAKIS - MADR 04/QCBS/2008 - no. 3166, 2010.

[12] Neres M. A., Castagnara D. D., Mesquita E. E., Zambom M. A., Cristine de Souza L., Rabello de Oliveira P. S., Jobim C. C. Production of alfalfa hay under different drying methods, Revista Brasileira de Zootecnia, on-line version ISSN 1806-9290, R. Bras. Zootec. vol.39 no.8 Viçosa, Aug. 2010.

[13] Nedelcu A., Ciupercă.R., Zaica A., Pruteanu A.M., Researches on Hay Ventilation With Air Heated in a Solar Panel, Volum International Symposium „Agricultural and Mechanical Engineering 2013”, ISSN 2344-4118, Bucharest, pp.9...14, 2013. 